\title{
Effect of Liquid Chlorophyll from Alfalfa Leaves (Medicago sativa $l$ ) as a Supportif Suplement to The Performance of Broiler Chickens
}

\author{
Ela Zabeta Ningrum ${ }^{1}$, Lalu Faisal Fajri ${ }^{1}$, and Dina Oktaviana ${ }^{1}$ \\ Faculty of Veterinary Medicine, Universitas Nusa Tenggara Barat \\ Corresponding author : dinaoktaviana@yahoo.com
}

\begin{abstract}
The purpose of this research is to determine the effect of liquid chlorophyll $8 \mathrm{ml}$ can affect the weight, weight of cut, and carcass weight applied by broiler breeders in West Nusa Tenggara provision, especially Lombok. The type of the research that conducted in this research is laboratory experimental research with Randomized Post Test Design Only Control Group Design. This research uses a complete randomized design (RAL) with 4 kinds of treatment are arranged in random. The research used 24 samples of 1 day old chickens (DOC) maintained for 35 days, Liquid chlorophyll was administered through drinking water. The results of this research is using ANOVA variety using SPSS for windows 17 uji duncan stated that P0 was significantly different from P1, P2 and P3 in the weight test Body, cutting weight and carcass weight.
\end{abstract}

Keywords: Liquid chlorophyll, performa, broiler chicken

\section{Introduction}

The need for animal protein, especially in the province of West Nusa Tenggara is very high, it can be proven by the increasing population and public awareness that animal protein is needed to meet nutritional needs, so the need for animal protein is also increasing. The animal is broiler chicken meat. Chicken is one of the most consumed sources of animal protein by the people of Indonesia, in addition to fish and eggs (National Socio-Economic Survey, 2013).

Growth in broilers has experienced rapid development over the past 30 years, mainly due to the advancement of genetic selection, improvement in feed quality, and regulation of suitable environmental conditions of the cage, so that the final body weight of $2 \mathrm{~kg}$ has been achieved in only 33 days (Sahraei, 2012)

Constraints faced by broiler breeders are expensive commercial feed. High protein content in commercial rations causes the price of rations to be relatively expensive. This is a problem in livestock business, good feed is a ration that contains all the food substances needed by animals in comparisons according to their needs. However, rations that are already complete in their food ingredients cannot guarantee the broiler's appearance will be better. The efficiency of a food is determined by the ability of livestock to digest food because not all food substances can be digested and absorbed by the digestive tract. 
The fitogenic use of recent years as feed ingredients has increased, both in terms of science and commercialization. Phytogenic is a natural bioactive compound derived from plants (herbs, spices or other plants), herbal plants as feed ingredients contain high fiber. But the benefits of using herbs as feed ingredients are high content of organic matter, pigments, vitamins and minerals and can be used in fresh form in poultry, can be used as feed ingredients with the aim of improving the appearance of livestock production and health through its influence on the dynamics of microflora and especially in digestive function

Liquid chlorophyll or chlorophyillin based on alfalfa leaf chlorophyll extract (Medicago sativa L.), chlorophyll or the main pigment of this plant is used as a food supplement that is used to help optimize metabolic functions, the immune system, detoxification, relieve inflammation (balance) and balance the system hormonal, chlorophyll also stimulates the formation of blood because it provides the basic ingredients of forming hemoglobin (Limantara, 2007). Parman and Harnina's (2008) study also proved that Alfalfa plants have high protein content and chlorophyll four times other vegetable plants. Description of the background of the above problems, the researchers are interested in conducting research with the title: "The Effect of Giving Liquid Chlorophyll from Alfalfa Leaves (Medicago sativa L) as Supportive Supplements for Broiler Chicken Performance"

The aims to be achieved in this research was to determine the effect of giving Liquid Chlorophyll from alfalfa leaves to increase body weight, cut weight, and carcass weight in broiler chickens.

\section{Materials and Methods}

\section{Materials}

Place and time of research

This research was conducted from June to July 2017 for 35 days. Maintenance site in Teruai village, Pujut District, Central Lombok Regency. Sample examination will be carried out at the Laboratory of the Faculty of Veterinary Medicine, University of West Nusa Tenggara to examine body weight, cut weight and carcass weight of broiler chickens.

Types, Design and Amount of Research

The type of research is carried out in this research was laboratory experimental research with a randomized post test only control group design. This study uses a completely randomized design (CRD) with 4 different treatment types arranged randomly. This design is used if the experiments used are relatively homogeneous / uniform such as cages, DOC age, cage equipment, maintenance management and ambient temperature except treatment. Thus the test required is as much as: 


$$
\begin{array}{ccc}
\text { Rumus: } \mathrm{t}(\mathrm{n}-1) & \geq 15 & \text { Information: } \\
4(\mathrm{n}-1) & \geq 15 & \mathrm{t}=\text { treatment } \\
4 \mathrm{n}-4 & \geq 15 & \mathrm{n}=\text { test } \\
4 \mathrm{n} & \geq 19 & \text { Source: (Kusriningrum, 2008) } \\
\mathrm{n} & \geq 4,75 &
\end{array}
$$

The required number of repetitions is 4.75 and rounded up to 5 repetitions for each treatment. So that the number of broiler chickens needed is 20 chickens.

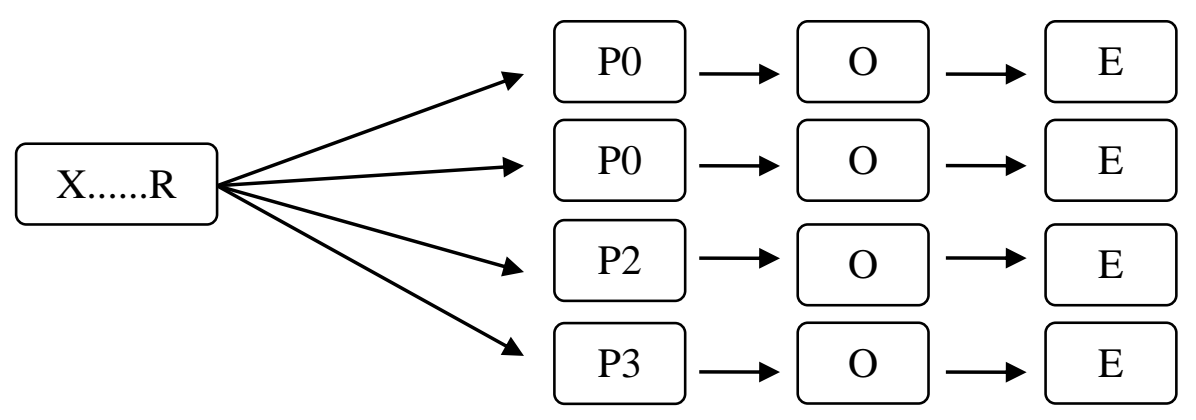

Information :

$\mathrm{X}=1$ week adaptation period

$\mathrm{R}=$ Randomization

P0 = Normal Group (Control Chicken Group)

$\mathrm{P} 1=$ Treatment 1 (Group of chickens are given $8 \mathrm{ml}$ chlorophyll liquid liquid / 1 liter of water).

P2 = Treatment 2 (Group of chickens are given $10 \mathrm{ml}$ of chlorophyll liquid Lquid / 1 Liter of water).

P3 = Treatment 3 (Chicken group are given $15 \mathrm{ml}$ liquid chlorophyll / 1 liter of water).

$\mathrm{O}=$ Observation

$\mathrm{E}=$ Evaluation

Research Population and Samples

The population of this research was 1 day old broiler chicken (DOC) obtained at PT. Charoen Pokphand Jaya Farm. The sample used in this study was 20 healthy broiler chickens.

Chicken cages, grain, broding rings, room thermometers, incandescent lamps, feed containers, drinking water containers, buckets, masks, handscones, books or sheets of paper, pens, syringes, knives, analytical scales, ballast, tissue paper. Broiler chicken, Liquid Chlorophyll, Chicken Feed, Vitamins, Vaccines, medicines and Chicken Drinks (water). Liquid chlorophyll is a liquid obtained from Alfalfa leaves (Medicago sativa L), using Green Fusion technology (binding to the power of solar energy), which contains various active substances that can increase antibodies and provide antioxidant properties, such as vitamins: A, B1, B2, B6, B12. 


\section{Methods}

Animal Preparation

Day Old Chiken (DOC) or 1 day broiler chickens as many as 20 will be used in the experiment, the chicken will be adapted for 7 days. The number of chickens is divided into 4 groups with the number of 5 chickens in 1 group which will be placed in 4 cages measuring $2 \times 1 \mathrm{~m}$.

Preparation of giving Liquid Chlorophyll

Liquid Chlorophyll is given by mixing it with chicken drinking water. Liquid Chlorophyll is given by mixing it with chicken drinking water at a dose of $8 \mathrm{ml} / 1$ liter of water in group P1, a dose of $10 \mathrm{ml} / 1$ liter of water in P2 group and a dose of $15 \mathrm{ml} /$ liter of water in the $\mathrm{P} 3$ group. Liquid Chlorophyll is given according to the dosage that has been determined during chicken maintenance. the dosage that has been determined is given Liquid Chlorophyll starting after the 8th day until the 35th day.

Preparation of Normal Treatment

Normal treatment is done by giving supplements and additional vitamins at scheduled times. Normal treatment will be given to group $\mathrm{P} 0$ without the administration of Liquid chlorophyll.

Work procedures

The work procedure in this reaearch was first, broiler chickens aged 1 day chicken were weighed with the aim of equalizing the weight of starter chickens using analytical scales. Chickens are grouped in 4 groups consisting of 5 chickens. The P0 group was given the normal treatment of groups P1, P2 and P3 given the treatment of Liquid Chlorophyll. Long maintenance of broiler chickens around 1 - 35 days. the adaptation period of 1-7 days, the 8th day until the day 35 of the chicken will be treated after that the chicken will be measured body weight and carcass weight by weighing.

Treatment of each group, namely:

1. P0 group (control control group): This group is used as maintenance in the community using, broiler chicken maintenance procedures. After 35 days the chickens will be measured weight, cut weight and carcass weight by weighing and recording.

2. Group P1 (group given Liquid Chlorophyll): Group 2 is given Liquid Chlorophyll in drinking water with a ratio of $8 \mathrm{ml} / 1$ liter of water. The treatment of giving Liquid Chlorophyll was carried out from day 8 to day 35 . After 35 days the chicken will be measured weight, cut weight and carcass weight by weighing and recording.

3. P2 group (the group given Liquid Chlorophyll): Group 3 is given Liquid Clhorophyll in drinking water with a ratio of $10 \mathrm{ml} / 1$ liter of water. The treatment of giving 
Liquid Chlorophyll was carried out from day 8 to day 35. After 35 days the chicken will be measured weight, cut weight and carcass weight by weighing and recording.

4. P3 group (group given Liquid Chlorophyll): Group 3 is given Liquid Chlorophyll in drinking water with a ratio of $15 \mathrm{mg} / 1$ liter of water. The treatment of giving liquid chlorophyll is carried out from day 8 to day 35. After 35 days the chicken will be measured weight, cut weight and carcass weight by weighing and recording.

Examination of body weight: Weighing carried out every week by using analytical scales, weighing starts from age 1 day (DOC) until the 7 th day after reaching k-7 days the chicken will be weighed recorded as the result of weight 1 week, then weighing chicken obtained after reaching k-14 days are recorded as the results of week $\mathrm{k}-2$ weight, after the 21 st day the chicken will be weighed and recorded its weight as a result of week k-3 weight, then weighing on the 28th day is recorded as weight week k4 and after reaching k-35 days weighing was obtained and recorded as k-5 week weight results.

Cut weight inspection: Chicken weighing obtained after post-harvest or when chickens have reached k-5 week the weighing is recorded as a result of cutting weight.

\section{Examination of Carcass Weight Percentage}

The percentage of carcass weight is obtained by comparing the weight of chickens without feathers, blood, head, neck, legs and internal organs (grams) with cutting weight (grams) multiplied by $100 \%$. The chicken that has been revoked and then processed further into a carcass by separating the head, neck, lower leg and internal organs (innards) and weighed to obtain carcass weight.

\section{Data Analysis}

The experimental design is used in this research was a completely randomized design. The data obtained, namely cutting weight and carcass weight were analyzed by analysis of variance (ANOVA) and continued with Duncan test (Mattjik, 2002).

\section{Result and Discussion}

\section{Broiler chicken body weight}

This research used 1 day old broiler chickens which were kept for 5 weeks. Broiler chickens number 20, with 5 samples per group. The group in this research consisted of 4 groups, namely P1 was control control, P2 was given $8 \mathrm{ml}$ liquid chloropyill / 1 liter of water, P3 was given liquid chloropyill $10 \mathrm{ml} / 1$ liter of water, and P4 was given liquid chloropyill $15 \mathrm{ml} / 1$ liter of water, heavy examination body The results of the examination of the average body weight in broiler chickens can be seen in the table below: 
Table 1. Average body weight of broiler chickens

\begin{tabular}{ccc}
\hline NO & Treatment & Average \pm SD \\
\hline 1 & P0 & $1145.2000^{\mathrm{a}} \pm 91.10818$ \\
2 & P1 & $1275.8000^{\mathrm{b}} \pm 36.96214$ \\
3 & P2 & $1318.8000^{\mathrm{b}} \pm 38.24526$ \\
4 & P3 & $1435.2000^{\mathrm{c}} \pm 128.51148$ \\
\hline
\end{tabular}

Description: ${ }^{\text {abc }}$ Superskrips letters are in the column ( $\left.\mathrm{p}<0.05\right)$, P0 is the control group which shows a significant difference to $\mathrm{P} 1, \mathrm{P} 2$ and $\mathrm{P} 3$ while $\mathrm{P} 1$ is not significantly different from $\mathrm{P} 2$ but $\mathrm{P} 1$ is significantly different from $\mathrm{P} 3$ and $\mathrm{P} 1$ while $\mathrm{P} 3$ is different $\mathrm{It}$ is obvious that $\mathrm{P} 1$ and $\mathrm{P} 2$ are liquid chlorophyll treatment groups with a dose of P1 $8 \mathrm{ml} / 1$ liter of water, P2 dose of $10 \mathrm{ml}$ / 1 liter of water, and $\mathrm{P} 3$ with a dose of $15 \mathrm{ml} / 1$ liter of water.

The difference in the results of the statistical analysis shows that the administration of liquid chlorophyll in drinking water can affect broiler body weight based on one way ANOVA analysis of variance with Duncan test. while P3 is significantly different from $\mathrm{P} 0, \mathrm{P} 1$ and $\mathrm{P} 2$.

\section{Cut broiler chicken weight}

This research used 1 day old broiler chickens which were kept for 5 weeks. Broiler chickens number 20, with 5 samples per group. The group in this study consisted of 4 groups, namely P1 was control, P2 was given $8 \mathrm{ml}$ liquid chloropyill / 1 liter of water, P3 was given liquid chloropyill $10 \mathrm{ml} / 1$ liter of water, and P4 was given liquid chloropyill $15 \mathrm{ml} / 1$ liter of water, weight inspection The results of the examination of the average cut weight in broiler chickens can be seen in the table below:

Table 2. The average weight of broiler chicken cut

\begin{tabular}{lll}
\hline NO & Treatment & Average \\
\hline 1 & P0 & $1119.00^{\mathrm{a}}$ \\
2 & P1 & $1282.00^{\mathrm{b}}$ \\
3 & P2 & $1348.00^{\mathrm{bc}}$ \\
4 & P3 & $1411.60^{\mathrm{c}}$ \\
\hline
\end{tabular}

Description: ${ }^{\text {abc }}$ Superskrips letters are in the column ( $\left.\mathrm{p}<0.05\right)$, P0 is the control group which shows a significant difference to P1, P2 and P3 while P1 is not significantly different from $\mathrm{P} 2$ but $\mathrm{P} 1$ is significantly different from $\mathrm{P} 3$ and $\mathrm{P} 1$ while $\mathrm{P} 3$ is different It is obvious that $\mathrm{P} 1$ and $\mathrm{P} 2$ are liquid chlorophyll treatment groups with a dose of P1 $8 \mathrm{ml} / 1$ liter of water, P2 dose of $10 \mathrm{ml}$ / 1 liter of water, and P3 with a dose of $15 \mathrm{ml} / 1$ liter of water. 
The difference in the results of statistical analysis shows that the administration of liquid chlorophyll in drinking water can affect broiler chicken body weight based on analysis of variance of one way ANOVA with Duncan test. Significant differences were seen in group $\mathrm{P} 0$ compared to groups $\mathrm{P} 1, \mathrm{P} 2$ and $\mathrm{P} 3$.

\section{Carcass weight of broiler chicken}

This research used 1 day old broiler chickens which were kept for 5 weeks. Broiler chickens number 20, with 5 samples per group. The group in this research consisted of 4 groups, namely P1 was control, P2 was given $8 \mathrm{ml}$ liquid chloropyill / 1 liter of water, P3 was given liquid chloropyill $10 \mathrm{ml} / 1$ liter of water, and P4 was given liquid chloropyill $15 \mathrm{ml} / 1$ liter of water, weight inspection The results of the examination of the average carcass weight in broiler chickens can be seen in the table below:

Table 3. Average carcass weight of broiler chickens:

\begin{tabular}{lll}
\hline NO & Treatment & Average \\
\hline 1 & P0 & $753.00^{\mathrm{a}}$ \\
2 & P1 & $861.20^{\mathrm{b}}$ \\
3 & P2 & $887.40^{\mathrm{b}}$ \\
4 & P3 & $926.40^{\mathrm{b}}$ \\
\hline
\end{tabular}

Remarks: ${ }^{a b}$ the Superskrips letter in the column ( $\left.\mathrm{p}<0.05\right)$, P0 is the control group that shows a significant difference in $\mathrm{P} 1, \mathrm{P} 2$ and $\mathrm{P} 3$ while $\mathrm{P} 1$ is not significantly different from $\mathrm{P} 2$ and $\mathrm{P} 3$, liquid chlorophyll treatment with a dose of P1 $8 \mathrm{ml}$ / 1 liter of water, P2 dose of $10 \mathrm{ml} / 1$ liter of water, and P3 with a dose of 15 $\mathrm{ml} / 1$ liter of water.

The difference in the results of the statistical analysis shows that the administration of liquid chlorophyll in drinking water can affect broiler body weight based on the analysis of variance of one way ANOVA with Duncan's test. The significant difference is seen in the P0 group compared to groups P1, P2 and P3.

\section{Carcass weight of broiler chicken (\%)}

This reaerch used 1 day old broiler chickens which were kept for 5 weeks. Broiler chickens number 20, with 5 samples per group. The group in this research consisted of 4 groups, namely P1 was control, P2 was given $8 \mathrm{ml}$ liquid chloropyill / 1 liter of water, P3 was given liquid chloropyill $10 \mathrm{ml} / 1$ liter of water, and P4 was given liquid chloropyill $15 \mathrm{ml} / 1$ liter of water, weight inspection The results of the examination of the average carcass weight in broiler chickens can be seen in the table below: 
Table 4. Carcass weight of broiler chickens (\%)

\begin{tabular}{lcccc}
\hline \multirow{2}{*}{ Parameters observed } & \multicolumn{4}{c}{ Awarding liquid chlorophyll } \\
\cline { 2 - 5 } & $\mathrm{P} 0$ & $\mathrm{P} 1$ & $\mathrm{P} 2$ & $\mathrm{P} 3$ \\
\hline Cut weight $(\mathrm{g})$ & $1119.00 \mathrm{~g}$ & $1282.00 \mathrm{~g}$ & $1348.00 \mathrm{~g}$ & $1411.60 \mathrm{~g}$ \\
Carcass weight $(\mathrm{g})$ & $753.00 \mathrm{~g}$ & $861.20 \mathrm{~g}$ & $887.40 \mathrm{~g}$ & $926.40 \mathrm{~g}$ \\
Weight percentage & 67,29 & 67,12 & 65,83 & 65,62 \\
Carcass (\%) & & & & \\
\hline
\end{tabular}

Description: Different superscripts on the same line show significant differences ( $p$ $<0.05)$.

Provision of liquid chlorophyll mixed into drinking water, with the use of liquid chlorophyll $8 \mathrm{ml}, 10 \mathrm{ml}$ and $15 \mathrm{ml}$ has a significant effect on broiler body weight, this is related to the very real feed consumption so that real weight growth in the three treatments. To obtain a high increase in body weight, a high feed consumption is also needed. Broiler chicken slaughter age 35 days between treatment groups. The higher the provision of liquid chlorophyll in drinking water can increase the weight of broiler chicken cut. This is due to the liquid chlorophyll active substance which is able to increase antibodies and provide antioxidant properties, such as vitamins: A, B1, B2, B6, B12, niacine, pantothenicacid, biotin, PABA (p-aminobenzoic acid), inositol, choline. Liquid chlorophyll has a significant effect $(\mathrm{P}<0.05)$ on the percentage of carcass. The average percentage of carcass obtained in this study ranged from $65.62 \%$ to $67.29 \%$. The percentage of broiler carcass varies between $65-75 \%$ of body weight, the more weight the chicken is cut, the higher the carcass. The percentage of broiler carcasses ranges from $65.35 \%$ to $66.56 \%$ (Daud., Et al., 2007). The addition of Liquid Chlorophyll in this study shows that the use of Liquid Chlorophyll $8 \mathrm{ml}$ to $15 \mathrm{ml}$ is able to improve the percentage of carcass compared to without the addition of Liquid Chlorophyll (control), this can be caused by the presence of high B12 content. B12 which can stimulate the growth of LAB in the intestine, so that food absorption becomes more efficient, and has an impact on body weight gain which indirectly affects the percentage of carcass. The use of B12 turned out to affect body weight gain, and carcass production expressed by the percentage of carcass was influenced by the final body weight and carcass weight, in chlorofill it also had the same structure with hemoglobin, the red pigment in human blood. This structural similarity causes chlorophyll molecules to be easily accepted in body tissues naturally (Limantara, 2009). The difference is only in the central atom of the molecule. The central atom of chlorophyll is magnesium $(\mathrm{Mg})$ while the central atom of hemoglobin is iron $(\mathrm{Fe})$. In the metabolic process, energy for humans comes from red blood cells that carry oxygen into the cells of the body of broiler chickens.

Hemoglobin is a molecule in red blood cells that carries oxygen. The chlorophyll is the fastest forming red blood cells in the body. By consuming chlorophyll, the number of blood cells can increase very rapidly, so that the energy supply in the body 
can continue to be guaranteed optimal absorption of nutrients which can be seen from the total feed spent for 5 weeks which is 3000 grams per fish for all treatments. The highest cutting weight was in the treatment without liquid chlorophyll, which was 1.235 $\mathrm{g} /$ head while the lowest was in the treatment with liquid chlorophyll dose which was $1.220 \mathrm{~g} / \mathrm{head}$. According to Resnawati and Hardjoworo (1976), carcass weight is directly related to cutting weight. The highest value on carcass weight without liquid chloropyill is $808 \mathrm{~g} /$ head while the lowest is treatment with liquid chlorophyll which is $813 \mathrm{~g} /$ head.

Besides B12 chlorophyll also contains of vitamin $\mathrm{C}$ which is one of the antioxidants that plays a role in maintaining and maintaining the integrity of the erythrocyte membrane. Chlorophyll contained in alfalfa is high enough to increase blood production and balance the function of the body, vitamin $\mathrm{C}$ which has an important function in the metabolic system and growth, which in growth is closely related to collagen formation. Robertson and Edwards (1996) state that the right administration of vitamin $C$ is very important because vitamin $C$ is involved in the synthesis of collagen tissue which means it is very influential on growth. In addition, in the formation of red blood cells that accelerate the absorption of Fe minerals from the small intestinal mucosa and directly into the bloodstream and then form hemoglobin. This depends on the condition of $\mathrm{pH}$ and oxygen dissolved in water. in the small intestine (duodenum), so that it can be easily absorbed (Almatser, 2009).

Water is useful for regulating feed digestibility, regulating temperature stability, helping to excrete waste and metabolism, maintain health, and transport nutrients in the body. Water content in 1 week old chicks is around 85\% and adult chickens aged 42 weeks are around $55 \%$. The water content in the body is $\pm 80 \%$, so the lack of water is very influential in the body of livestock. Hungry animals can lose all glycogen, fat and half the body's protein and $40 \%$ of body weight can still be alive. If you lose $10 \%$, there will be a weight loss and if a deficiency of $20 \%$ can result in death.

\section{Conclusion}

Based on the results of the research, the conclusions are:

1. Provision of Liquid Chlorophyll has a significant effect on increasing body weight, cutting weight and carcass weight of broiler chicken.

2. The addition of liquid chlorophyll to $\mathrm{P} 3(15 \mathrm{ml})$ significantly affected $\mathrm{k}-2$ treatment on increasing body weight, cutting weight and carcass weight of broiler chicken.

\section{References}

Agustina dan Purwanti. 2012. Ilmu Nutrisi Unggas. Rumah Pengetahuan. Solo

Daud, M., W. G. Piliang dan P. Kompiang. 2007. Persentase dan kualitas karkas ayam pedaging yang diberi probiotik dan prebiotik dalam ransum. JITV, 12 (3): 167174.

Kusriningrum, 2008.Rancangan Percobaan. Surabaya: Airlangga University Pres. Label 001.434. KUSP. 
Limantara L. 2007. Mengapa Kita Butuh Makanan Tambahan / Food Suplemen 6 Juli 2008.

Limantara L.2009. Daya penyembuhan klorofil Malang: Ma Chung Press; 2009

Mattjik, A.A. 2002. Perancangan Percobaan dengan Aplikasi SAS dan Minitab. Edisi ke-2. IPB Press, Bogor.

North, M.O dan D.D. Bell. 1990. Commercial Chicken Production Manual, 4 thEdit. Chapman and bHall, New York USA.

Parman, S dan S. Harnina. 2008. Pertumbuhan, Kandungan Klorofil dan Serat Kasar pada Defoliasi Pertama Alfalfa Akibat Pemupukan Mikorisa. Bull.Anatomi dan Fisiologi UNNES Semarang. 16 (2): 6

Resnawati, H. dan P. Hardjosworo.1976. Pengaruh Umur terhadap Persentase Karkas danEfisiensi Ekonomis pada Ayam Broiler Unsexed. Lembaran LPP IV.

Sahraei, M. 2012. Feed restriction in broiler chickens production. A. Review Global Veterinaria 8 (5): 449458.

Survey Sosial Ekonomi Nasional 2013. pdf. Diakses tanggal 22 Januari 2016 